\section{Biodiesel Blends}

Biodiesel is a domestically produced, renewable fuel that can be manufactured from new and used vegetable oils, animal fats, and recycled restaurant grease. Biodiesel's physical properties are similar to those of petroleum diesel, but the fuel significantly reduces greenhouse gas emissions and toxic air pollutants. It is a biodegradable and cleaner-burning alternative to petroleum diesel.

Biodiesel can be blended and used in many different concentrations. They include B100 (pure biodiesel), B20 ( $20 \%$ biodiesel, $80 \%$ petroleum diesel), B5 (5\% biodiesel, 95\% petroleum diesel), and B2 (2\% biodiesel, 98\% petroleum diesel). The most common biodiesel blend is B20, which qualifies for fleet compliance under the Energy Policy Act (EPAct) of 1992.

\section{Can I use B20 in my vehicle's diesel engine?}

As long as the vehicle was manufactured after 1993, biodiesel can be used in diesel engines and fuel injection equipment with little impact on operating performance. If your vehicle is older than that, beware. The engine could be assembled with incompatible elastomers, which can break down with repetitive high-blend biodiesel usage.

Regardless of your vehicle's age, it's a good idea to check original engine manufacturer (OEM) recommendations before using biodiesel. Most OEMs approve blends up to B5 in their vehicles. Some approve blends up to B20 if the fuel meets certain specifications and standards. One even approves B100 in certain types of farm equipment.

If you can't find OEM recommendations, check your engine manufacturer's Web site or speak with a dealer to determine the biodiesel blend that's right for your vehicle. In addition, you can find general information on the National Biodiesel Board (NBB) Web site (www.biodiesel. org/resources/fuelfactsheets/standards_and_warranties.shtm). Manufacturer-specific information is also available. ${ }^{1}$

\section{Is biodiesel readily available?}

Biodiesel is available in all 50 states. NBB tallies show that 450 million gallons of biodiesel were sold in 2007, up substantially from 2 million gallons in $2000 . .^{2}$ As of January 2008, the United States had an annual production capacity of more than 2.2 billion gallons. ${ }^{3}$
The number of retailers, petroleum distributors, and biodiesel distributors offering biodiesel blends continues to grow. According to the Alternative Fuels Station Locator tool on the Alternative Fuels and Advanced Vehicles Data Center (AFDC) Web site, there are more than 800 biodiesel fueling sites across the country. To look up biodiesel stations in your area, visit http://afdcmap2.nrel.gov/locator.

\section{Will biodiesel perform as well as diesel?}

Testing results of engines operating on B20 show similar fuel consumption, horsepower, and torque to those operating on conventional diesel. Biodiesel has some additional desirable characteristics, including a higher cetane number (a measure of the ignition value of diesel fuel) and higher lubricity (the capacity for reducing friction) than U.S. diesel fuel. B20 also has an energy content between those of \#1 and \#2 diesel fuels.

\section{Will biodiesel perform well in cold weather?}

Just like common \#2 diesel, certain high-freezing-point compounds in biodiesel will crystalize in very cold temperatures. Pure biodiesel crystalizes in warmer temperatures than \#2 diesel fuel, but B20 blends are administered with the same fuel management techniques as \#2 diesel. As temperatures get colder, proper blending for B20 becomes more critical, and the fuel's sensitivity to process variations increases. Blends of 5\% biodiesel and below have a small impact on cold-flow properties (measures of low temperature operability). For more information on cold-flow properties and biodiesel handling, download Biodiesel Handling and Use Guidelines from www.nrel.gov/ vehiclesandfuels/npbf/pdfs/40555.pdf.

\section{Will biodiesel plug my vehicle filters?}

Biodiesel has a solvent effect proportionate to the amount of biodiesel in the fuel. For example, B100 has a higher solvent effect than B20. This will clean your vehicle's fuel system and could release deposits accumulated on tank walls and in pipes from previous diesel fuel usage.

\footnotetext{
1 Source: www.biodiesel.org/pdf_files/OEM\%20Statements/oem_matrix.pdf

2 Source: www.biodiesel.org/pdf_files/fuelfactsheets/Production_Graph_Slide.pdf

3 Source: www.biodiesel.org/buyingbiodiesel/producers_marketers/ ProducersMap-Existing.pdf
} 
The release of deposits in higher biodiesel blends may initially clog filters, so you should be proactive in checking for and replacing clogged fuel filters. Once the build-up is eliminated, return to your regular replacement schedule. This issue is less prevalent with B20 and lower blends. There is no evidence that lower-blend levels plug filters.

\section{Will long-term biodiesel use affect my engine?}

Studies of B20 and lower blends have not shown longterm effects for in-specification biodiesel. In general, B100 can soften and degrade certain types of elastomers and natural rubber compounds over time. Using higher-level blends (above B20) can impact fuel system components (primarily fuel hoses and fuel pump seals) that contain elastomer compounds incompatible with biodiesel. The effect is lessened as the biodiesel blend level is decreased. For more information, visit $w w w$.biodiesel.org.

\section{Can I use vegetable oil in my diesel engine?}

Straight vegetable oil is not the same as biodiesel and is generally not considered an acceptable fuel for large-scale or long-term use. It is not a legal motor fuel, it doesn't meet biodiesel fuel specifications and quality standards, and it is not registered with the U.S. Environmental Protection Agency (EPA). For more information, download "Straight Vegetable Oil as a Diesel Fuel," a fact sheet available on the AFDC at www.eere.energy.gov/afdc/pdfs/39733.pdf.

\section{Is biodiesel cleaner burning than regular diesel?}

The use of biodiesel in conventional diesel engines substantially reduces emissions of unburned hydrocarbons (HC), carbon monoxide (CO), sulfates, polycyclic aromatic HCs, nitrated polycyclic aromatic HCs, and particulate matter (PM). The reductions of these compounds increase as the amount of biodiesel blended into diesel fuel increases. B100 provides the best emission reductions, but lowerlevel blends also provide benefits. B20 has been shown to reduce PM emissions by $10 \%, \mathrm{CO}$ by $11 \%$, and unburned HCs by $21 \%$ (see Figure 1). Studies of oxides of nitrogen emissions have provided contradictory results, and additional testing and analysis is ongoing.

Biodiesel use also reduces greenhouse gas emissions because the carbon dioxide released in biodiesel combustion is offset by the carbon dioxide sequestered while growing the feedstock. B100 use reduces carbon
Figure 1. Average Emission Impacts of Biodiesel for Heavy-Duty Highway Engines

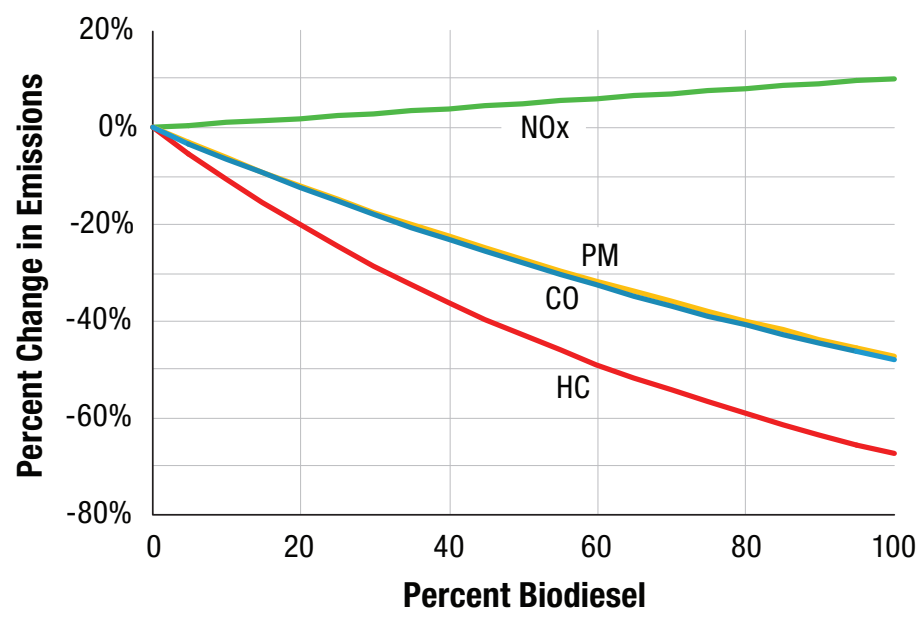

Source: EPA, Draft Report EPA 420-P-02-001, 0cotober 2002

dioxide emissions by more than $75 \%$ compared to diesel. Using B20 reduces carbon dioxide emissions by $15 \%$.

\section{Does biodiesel need to meet any standards?}

Biodiesel used in blends should meet specification D675107B, a standard set by ASTM International to ensure the quality of U.S. biodiesel used in blends. Biodiesel meeting this standard is legally registered as a fuel blendstock or additive with the EPA. As of January 2008, ASTM International was developing specifications explicitly for biodiesel blends.

\section{Are incentives and credits available for biodiesel?}

The American Jobs Creation Act of 2004 (Public Law 108-357) created tax incentives for biodiesel fuels, which are available to blenders and retailers. Section 1344 of EPAct 2005 extended the tax credit for biodiesel producers through 2008. The credits are $\$ 1$ per gallon of agri-biodiesel and $\$ .50$ per gallon of waste-grease biodiesel. For more information, visit the State and Federal Incentives and Laws section of the AFDC at www.eere. energy.gov/afdc/fuels/biodiesel_laws.html.

\section{Where can I find more information on biodiesel?}

Visit the Biodiesel section of the AFDC at www.eere.energy. gov/afdc/fuels/biodiesel.html.
Sponsored by the U.S. Department of Energy

Energy Efficiency and Renewable Energy

Vehicle Technologies Program

For more information contact: EERE Information Center 1-877-EERE-INF (1-877-337-3463)

www.eere.energy.gov

Prepared by the National Renewable Energy Laboratory (NREL) NREL is a U.S. Department of Energy National Laboratory Operated by Midwest Research Institute • Battelle

\begin{abstract}
A Strong Energy Portfolio for a Strong America
Energy efficiency and clean, renewable energy will mean a stronger economy, a cleaner environment, and greater energy independence for America. Working with a wide array of state, community, industry, and university partners, the U.S. Department of Energy's Office of Energy Efficiency and Renewable Energy invests in a diverse portfolio of energy technologies.
\end{abstract}

DOE/GO-102008-2542 • April 2008

Printed with a renewable-source ink on paper containing at least $50 \%$ wastepaper, including $10 \%$ postconsumer waste. 